\title{
Demographic, ecological and physiological responses of ringed seals to an abrupt decline in sea ice availability
}

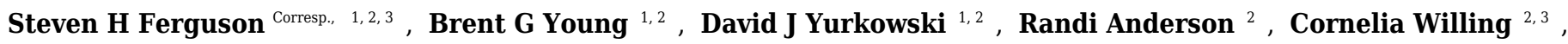 \\ Ole Nielsen ${ }^{1}$ \\ ${ }^{1}$ Fisheries and Oceans Canada, Winnipeg, Manitoba, Canada \\ 2 Department of Biological Sciences, University of Manitoba, Winnipeg, Manitoba, Canada \\ 3 Centre for Earth Observation Science, University of Manitoba, Winnipeg, Manitoba, Canada \\ Corresponding Author: Steven H Ferguson \\ Email address: steve.ferguson@dfo-mpo.gc.ca
}

To assess whether demographic declines of Arctic species at the southern limit of their range will be gradual or punctuated, we compared large-scale environmental patterns including sea ice dynamics to ringed seal (Pusa hispida) reproduction, body condition, recruitment, and stress in Hudson Bay from 2003-2013. Aerial surveys suggested a gradual decline in seal density from 1995-2013, with the lowest density occurring in 2013. Body condition decreased and stress (cortisol) increased over time in relation to longer open water periods. The 2010 open water period in Hudson Bay coincided with extremes in large-scale atmospheric patterns (NAO, AO, ENSO) resulting in the earliest spring breakup and the latest ice formation on record. The warming event was coincident with high stress level, low ovulation rate, low pregnancy rate, few pups in the Inuit harvest, and observations of sick seals. Results provide evidence of changes in the condition of Arctic marine mammals in relation to climate mediated sea ice dynamics. We conclude that although negative demographic responses of Hudson Bay seals are occurring gradually with diminishing sea ice, a recent episodic environmental event played a significant role in a punctuated population decline. 
1 Demographic, ecological and physiological responses of ringed seals to an abrupt decline in sea ice availability

3 Steven H. Ferguson*1,2,3, Brent G. Young ${ }^{1,2}$, David J. Yurkowski ${ }^{1,2}$, Randi Anderson ${ }^{2}$, Cornelia

$4 \quad$ Willing 2,3 , Ole Nielsen ${ }^{1}$

$5 \quad{ }^{1}$ Fisheries and Oceans Canada, 501 University Crescent, Winnipeg, MB, Canada

$6 \quad{ }^{2}$ Department of Biological Science, University of Manitoba, Winnipeg, MB, Canada

$7 \quad{ }^{3}$ Centre for Earth Observation Science, University of Manitoba, Winnipeg, MB, Canada

8

9 Corresponding Author:

10 Steven H. Ferguson

11 Fisheries and Oceans Canada, 501 University Crescent, Winnipeg, MB, Canada

12 e-mail: steve.ferguson@dfo-mpo.gc.ca 


\section{ABSTRACT}

15 To assess whether demographic declines of Arctic species at the southern limit of their range will be gradual or punctuated, we compared large-scale environmental patterns

17 including sea ice dynamics to ringed seal (Pusa hispida) reproduction, body condition, recruitment, and stress in Hudson Bay from 2003-2013. Aerial surveys suggested a gradual decline in seal density from 1995-2013, with the lowest density occurring in 2013. Body condition decreased and stress (cortisol) increased over time in relation to longer open water periods. The 2010 open water period in Hudson Bay coincided with extremes in large-scale atmospheric patterns (NAO, AO, ENSO) resulting in the earliest spring breakup and the latest ice formation on record. The warming event was coincident with high stress level, low ovulation rate, low pregnancy rate, few pups in the Inuit harvest, and observations of sick seals. Results provide evidence of changes in the condition of Arctic marine mammals in relation to climate mediated sea ice dynamics. We conclude that although negative demographic responses of Hudson Bay seals are occurring gradually with diminishing sea ice, a recent episodic environmental event played a significant role in a punctuated population decline. 
31

32

33

34

35

36

37

\section{BACKGROUND}

Organisms evolve specific adaptations to their habitats through natural selection (Mayr 1963) and when their habitats change gradually, organisms can adjust phenotypically within an evolved range of flexibility (Levins 1962). However, this evolved adaptation has limitations and in extreme situations, organisms may not be able to adapt to particular habitats and environmental conditions above an evolved threshold (Southwood 1977). Under these circumstances, populations suffer mortality of individuals, declines in reproduction, and/or immigrate to new habitats that may allow increased demographic success (MacArthur and Wilson 1966). The result is a shift in species distribution (Guisan and Thuiller 2005) and understanding this process by identifying thresholds to adaptability and the mechanism of population decline are both critical to species conservation.

Predicting how climate warming will result in retraction of an Arctic species range northward requires knowledge of demographic changes and their ecological plasticity in response to environmental change. Few studies have linked marine mammal demographic responses to climate change (Poloczanaska et al. 2007) with the notable exception of polar bears (Ursus maritimus) (Regehr et al. 2007; Hunter et al. 2010; Lunn et al. 2016), where the majority of research relates to loss of space and time opportunities for feeding on a lipid-rich diet (Thiemann et al. 2008; Rode et al. 2016). Ringed seals (Pusa hispida) have a circumpolar distribution and show high variability in the relative importance of predation from polar bears (Thiemann et al. 2008) and to varying food habits (Yurkowski et al. 2016a). However, key habitat attributes are linked to survival and successful reproduction. 
53 In particular, ringed seals require sea ice during the critical spring period when

54 reproduction and molting occurs (Smith \& Stirling 1975) and a seasonal pulse in food

55 availability in the summer ice-free season (Young \& Ferguson 2013). Evolved life history

56 characteristics that match these high-latitude environmental features include relative small

57 body size for a pinniped and a life history characterized by early age of maturation, annual

58 birthing, short lactation duration, widely varying but high pup mortality, relatively low

59 adult mortality, and greater fitness investment in long life (Ferguson \& Higdon 2006).

60

61

62

63

64

65

66

67

68

69

High latitude species are characterized by a strong seasonal cycle of feast and fast with both periods critical to reproduction and survival (Boyce 1979). Ringed seals are adapted to cycle annually from intensive foraging during the open water season to accumulate fat reserves to sustain them over winter and during the birthing, nursing, and mating periods when adults are restricted to small home ranges with depleted food resources (Luque et al. 2014; Young and Ferguson 2014). In spring, pups are independent and adults undergo molting with little feeding opportunities and increased risk of predation (Stirling and Archibald 1977; Young and Ferguson 2015). During periods of deteriorating environmental conditions, the phenology of ringed seals can be interrupted leading to inadequate energy reserves prior to the next year's reproduction (Harwood et al. 2012). Ringed seal populations can also be negatively affected by infrequent, annual, extreme climatic conditions that exert pressure on their demographics (Stirling and Smith 2004). resulting changes in ecological dynamics of the marine ecosystem (Post et al. 2013). 
75 Hudson Bay represents one of the most southerly distributions of ringed seals and

76 therefore, as an ice-obligate marine mammal, the prediction is for a retraction northward

77 in range (Kovacs \& Lydersen 2008). The Hudson Bay ecosystem is at the southern edge of

78 maximum sea ice extent and goes through a seasonal cycle of complete ice formation and

79 loss (Saucier et al. 2004). The initial characteristics of population and demographic changes

80 may already be occurring with a decrease in ringed seal density observed in western

81 Hudson Bay between the two recent aerial surveys in spring 2010 and 2013 (0.78 to

$820.20 / \mathrm{km}^{2}$ ) (Young et al. 2015).

83

84

Here, we compare indices in the productivity and health of the Hudson Bay ringed seal population with environmental covariates over time. Our data sets were annual trends in sea ice breakup and formation, major climatic indices, and biological data from seal collections, 2003-13: (1) body condition (\% fat) from seals harvested by Inuit, (2) reproduction from examination of reproductive tracts, (3) recruitment from hunter harvest statistics, and (4) stress from blubber cortisol levels. We hypothesize that gradual deteriorating change in sea ice characteristics will correlate with a gradual decrease in ringed seal body condition, ovulation rate and pup recruitment (Stirling 2005), whereas an abrupt decline in sea ice availability in 2010 will result in dramatic negative demographic, ecological and physiological responses by ringed seals.

\section{METHODS}

Sea ice breakup and freeze-up dates were determined from weekly data obtained from the Canadian Ice Service using Icegraph 2.0 (http://iceweb1.cis.ec.gc.ca/IceGraph/), for eastern Hudson Bay, 1979-2014. The majority of biological data for ringed seals was 
97 derived from the Sanikiluaq (southeast Hudson Bay) seal collection whereas Arviat

98 (southwest Hudson Bay) only provided the time-series of cortisol measures. Therefore, we

99 only present annual changes in sea ice coverage (Fig, $1 \mathrm{~b}$ ) for this eastern region

100 (Sanikiluaq) although we found strong correlations with other Hudson Bay regions

101 identified by the Canadian Ice Service. We were unable to assess the effect of east-west

102 differences (Young and Ferguson 2014) and how they may influence our results because

103 our datasets were not balanced (i.e., biological measures from Sanikiluaq were not

104 available from Arviat). Ice breakup date was defined as the date on which the sea ice

105 concentration decreased and remained below 50\% (Stirling et al. 1999). Conversely,

106 freeze-up date was defined as the date on which sea ice concentration increased and

107 remained above 50\%. Open-water duration was calculated by subtracting the breakup and

108 freeze-up dates. Major climatic indices were obtained from the Climate Prediction Center

109 (http://www.cpc.ncep.noaa.gov/), including the Arctic Oscillation (AO), the North Atlantic

110 Oscillation (NAO), and El Nino-Southern Oscillation (ENSO) for the December to February

111 monthly mean estimates from 1971-2014. We included ENSO due to its significant climatic

112 influence in North America and due to its effect on ecological relationships in several

113 ecosystems across the globe (Wang et al. 2010; Nye et al. 2014; Rustic et al. 2015). NAO

114 and AO were included since previous research found that they were related to ringed seal

115 recruitment and timing of spring ice breakup (Ferguson et al. 2005). The longer time frame

116 available for environmental data provided a background to the 2003-2013 period with

117 available ringed seal biological data.

118 Morphological measurements and tissue samples were collected from 1425 Hudson Bay

119 ringed seals harvested during the Inuit subsistence hunt from Sanikiluaq ( $n=917)$, NU, 
120 Canada $\left(56^{\circ} 32^{\prime} 34^{\prime \prime} \mathrm{N}, 79^{\circ} 13^{\prime} 30^{\prime \prime} \mathrm{W}\right)$ and Arviat (n=508), NU (61 $\left.6^{\prime} 29^{\prime \prime} \mathrm{N}, 94^{\circ} 3^{\prime} 25^{\prime \prime} \mathrm{W}\right)$

121 from 2003-2013. Permits to collect samples as part of the Inuit subsistence hunts were

122 acquired from Fisheries and Oceans Canada. All biological data with the exception of 123 cortisol was derived from seals collected by Sanikiluaq hunters in the eastern region of

124 Hudson Bay. Samples were collected in autumn (Oct. to Dec.) in Arviat. In Sanikiluaq some 125 samples were collected throughout the year but we used only autumn collections for 126 age/sex composition as the late open-water season provides a representative sample of the 127 population (see Holst et al. 1999; Ferguson et al. 2005). Permits to collect samples as part 128 of the Inuit subsistence hunts were acquired from Fisheries and Oceans Canada. Canine 129 teeth were extracted from the lower jaw for age determination using annual growth layer 130 groups in the cementum (Chambellant and Ferguson 2009). Pup survival was defined as 131 the percentage of pups (i.e., <1 year) in the autumn subsistence hunt and is considered a 132 good measure of 0-6 month survival (Chambellant et al. 2012). Total body weight and sculp 133 weight (weight of blubber layer, skin and fur) were recorded by the hunters at the time of 134 sample collection. Body condition was calculated as percent blubber (sculp weight*100 / 135 total bodyweight). Reproductive tracts were stored frozen before being examined. After 136 gross examination of reproductive tracts, ovaries were excised, formalin-fixed and 137 sectioned at 2-mm intervals, and examined macroscopically for the presence of a corpus 138 luteum (ovulation in the year of collection) and corpora albicantia (previous pregnancies) 139 (Laws 1956). Estimation of ovulation was only calculated if sample size for a particular 140 year exceeded 5 mature adult females which excluded 2003-6. An extraction method for 141 ringed seal blubber samples was used in conjunction with radioimmunoassay to measure 
142 cortisol levels representing stress (Trana et al. 2014). Cortisol measures from Arviat seals

143 were not available in 2013.

Four separate general linear models were used to investigate relationships between

145 environmental (i.e. duration of the open water period, ENSO, NAO and AO indices) and

146 biological variables (i.e. percentage of ovulating females, percentage of pups in the harvest,

147 body condition and cortisol levels) over time using R v 3.2.3 (R Core Team 2015).

148 Continuous predictor variables were screened for collinearity and removed when a

149 Pearson's correlation coefficient was $\geq 0.6$ and a variance inflation factor (VIF) was $>3.0$.

150 NAO and AO were highly correlated (0.8). We retained NAO for all analyses due to its

151 stronger association with sea ice (Nakamura et al. 2015). Prior to analysis, percentage of

152 ovulating females, percentage of pups in harvest, and body condition were normally

153 distributed upon visual examination of histograms and quantile-quantile plots. Cortisol

154 levels were log-transformed before analysis to improve normality.

RESULTS

156

157

158

159

160

161

162

163

Results support a gradual pattern of earlier spring ice breakup and later autumn freeze-up in Hudson Bay; where from 2003-2013, sea ice breakup has varied more widely than freeze-up. No relationship occurred with any climate variability index over 1979-2014, but the NAO and AO have been more positive from 1999-2015 (Fig. 1). The longest ice-free season on record for eastern Hudson Bay occurred in 2010, with the earliest spring breakup (May) and latest freeze-up (January 2011) and an anomalous negative NAO and AO, and a high ENSO index (Fig. 1). 
164 Figure 1. Top: Annual winter (December to February) North Atlantic Oscillation index 165 (NAO), Arctic Oscillation (AO), and El Nino-Southern Oscillation (ENSO), 1971-2014. Note 166 red arrows indicate possible regime shifts $(1977,1989,1989 / 99,2010)$ and black arrows 167 possible years with poor ringed seal condition: 1973/74, 1983, 1992, 1998, 2010 (Smith 168 and Stirling 1978; Hare and Mantua 2000; Smith and Harwood 2001; Benson and Trites 169 2002; Ferguson et al. 2005; Litzow 2006). Bottom: Sea ice patterns over the day of the year 170 showing inter-annual variation in timing of spring breakup, duration of open water season, 171 and time of freeze-up, 2003-2013. Note that autumn 2010 freeze-up did not occur until 172 January 2011. 

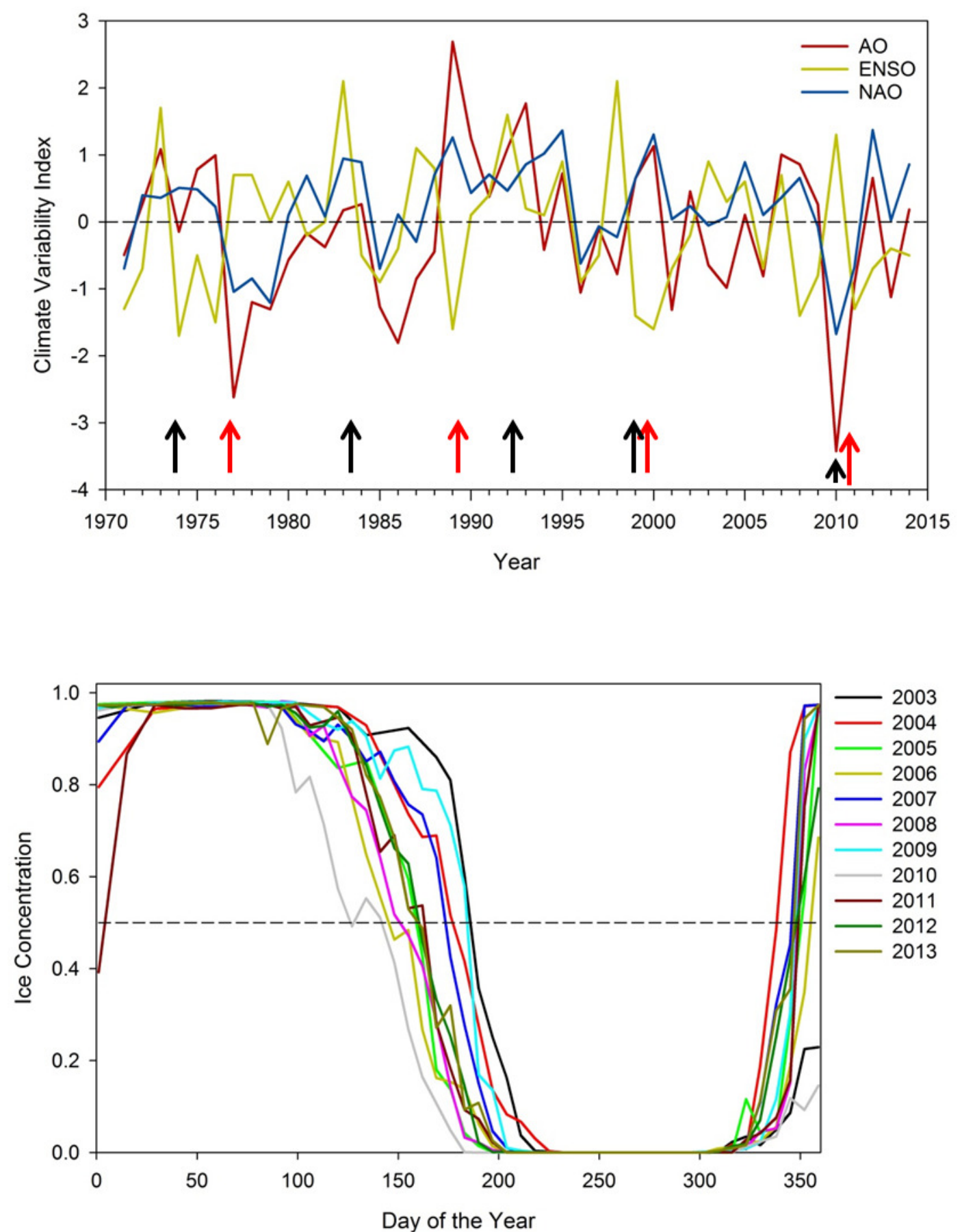

174

Day of the Year

175

176 
178 blubber mass in 2004 to $40.3 \%$ in 2012 before increasing to $48.1 \%$ in 2013 (Table 1; Fig.

179 2). In addition, body condition significantly decreased with increasing open water period ( $\mathrm{t}$ $180=-2.0, \mathrm{p}<0.05)$, ENSO index $(\mathrm{t}=-2.3, \mathrm{p}=0.02)$ and NAO index $(\mathrm{t}=-2.0, \mathrm{p}<0.05 ;$ Table 2;

181 Fig. 3). Ovulation rate varied considerably among years from $100 \%$ in 2008 to $56 \%$ in 182 2011, albeit with no relationship with year, open water duration, or climatic indices.

183 Percentage of pups in the harvest, as an estimate of pup survival, exhibited a marginal 184 decline from $2003-2013(t=-2.09, p=0.08)$ from about $40 \%$ of the harvest to about $20 \%$ 185 (Table 2; Fig 2). Stress, as measured by cortisol concentration (ng/g), significantly 186 increased over time $(\mathrm{t}=8.0, \mathrm{p}<0.001)$ from about 0.1 to $0.6 \mathrm{ng} / \mathrm{g}$ over the $2003-12 \mathrm{period}$ 187 (Table 2; Fig. 2). A significant decrease in cortisol level occurred with NAO index $(t=-2.6, p$ $188=0.01$; Fig. 3). In 2010, cortisol levels in ringed seals had the highest amount of variability 189 (standard deviation $=1.84$ ) compared to other years (Fig. 2). High stress levels occurred in 1902010 and low ovulation rates occurred in 2011 which supports the pattern of a decrease in 191 ovulation rate after the high stress levels.

192 Table 1. Biological data from harvested ringed seals collected in Hudson Bay, Canada. Mean \pm 193 standard error (sample size).

\begin{tabular}{ccccc}
\hline Year & $\begin{array}{c}\text { Body condition } \\
\text { (\% fat) }\end{array}$ & $\begin{array}{c}\text { Percent } \\
\text { Ovulation }\end{array}$ & $\begin{array}{c}\text { Percent Young of } \\
\text { Year }\end{array}$ & RIA Cortisol (ng/g) \\
\hline 2003 & & $39.1(115)$ & $0.07 \pm 0.01(72)$ \\
2004 & $55.4 \pm 1.0(45)$ & $30.4(56)$ & $0.10 \pm 0.02(32)$ \\
2005 & $52.8 \pm 0.9(71)$ & $40.9(88)$ & $0.10 \pm 0.01(120)$
\end{tabular}




$\begin{array}{lllll}2006 & 49.7 \pm 0.7(80) & & 42.7(82) & 0.14 \pm 0.05(40) \\ 2007 & 46.9 \pm 0.6(123) & 85.7(7) & 52.4(126) & 0.32 \pm 0.10(27) \\ 2008 & 47.5 \pm 0.8(102) & 100.0(5) & 48.6(105) & 0.24 \pm 0.04(56) \\ 2009 & 45.2 \pm 1.2(41) & 88.9(9) & 38.1(42) & 0.28 \pm 0.04(51) \\ 2010 & 43.9 \pm 0.9(90) & 66.7(18) & 28.1(96) & 0.86 \pm 0.27(46) \\ 2011 & 46.4 \pm 0.8(97) & 56.3(16) & 20.6(97) & 0.51 \pm 0.12(30) \\ 2012 & 40.3 \pm 1.2(65) & 83.3(12) & 10.8(65) & 0.43 \pm 0.07(34) \\ 2013 & 48.1 \pm 1.4(42) & 100.0(6) & 20.0(45) & \end{array}$

195

196 Table 2. Relationships between Hudson Bay ringed seal biological parameters and

197 environmental correlates assessed using general linear models, 2003-2013.

\begin{tabular}{|c|c|c|c|c|}
\hline Covariates & Ovulation rate $(\%)$ & Pup recruitment (\%) & $\begin{array}{l}\text { Seal condition } \\
\text { (blubber \%) }\end{array}$ & Cortisol (ng/g) \\
\hline Intercept & $-48.00 \pm 69.51$ & $41.96 \pm 39.1$ & $25.20 \pm 2.58^{* * *}$ & $-34.90 \pm 43.48^{* * *}$ \\
\hline Year & $0.02 \pm 0.03$ & $-0.021 \pm 0.020$ & $-0.012 \pm 0.001^{* * *}$ & $0.002 \pm 0.0002 * * *$ \\
\hline $\begin{array}{l}\text { Ice-free period } \\
\text { (days) }\end{array}$ & $0.0003 \pm 0.006$ & $-0.00036 \pm 0.0033$ & $-0.0003 \pm 0.0002^{\mathrm{a}}$ & $0.00003 \pm 0.0005$ \\
\hline $\begin{array}{l}\text { El-Niño Southern } \\
\text { Oscillation }\end{array}$ & $0.004 \pm 0.01$ & $0.0175 \pm 0.072$ & $-0.008 \pm 0.004^{*}$ & $0.001 \pm 0.006^{b}$ \\
\hline $\begin{array}{l}\text { North Atlantic } \\
\text { Oscillation }\end{array}$ & $0.011 \pm 0.012$ & $0.00719 \pm 0.072$ & $-0.009 \pm 0.004^{*}$ & $-0.02 \pm 0.007 *$ \\
\hline
\end{tabular}

$\mathrm{a}=0.08 ;^{\mathrm{b}}=0.055 ;^{*} \mathrm{P}<0.05 ;^{* *} \mathrm{P}<0.01 ;^{* * *} \mathrm{P}<0.001$

$\mathrm{R}^{2}$ was 0.40 for ovulation rate model, 0.19 for pup recruitment model, 0.12 for body condition model, and 0.21 for cortisol level model.

198

199 Figure 2. Barplots (A and B) of annual ovulation rates (\%) from adult female ringed seals

200 and annual percentage of pups in the harvest (Table 1). Linear regressions between seal 
201 body condition and harvest year ( $C$; slope $=-0.01, t=-8.2, p<0.001)$, and cortisol level and

202 harvest year (D; slope $=0.02, t=8.0, p<0.001)$.
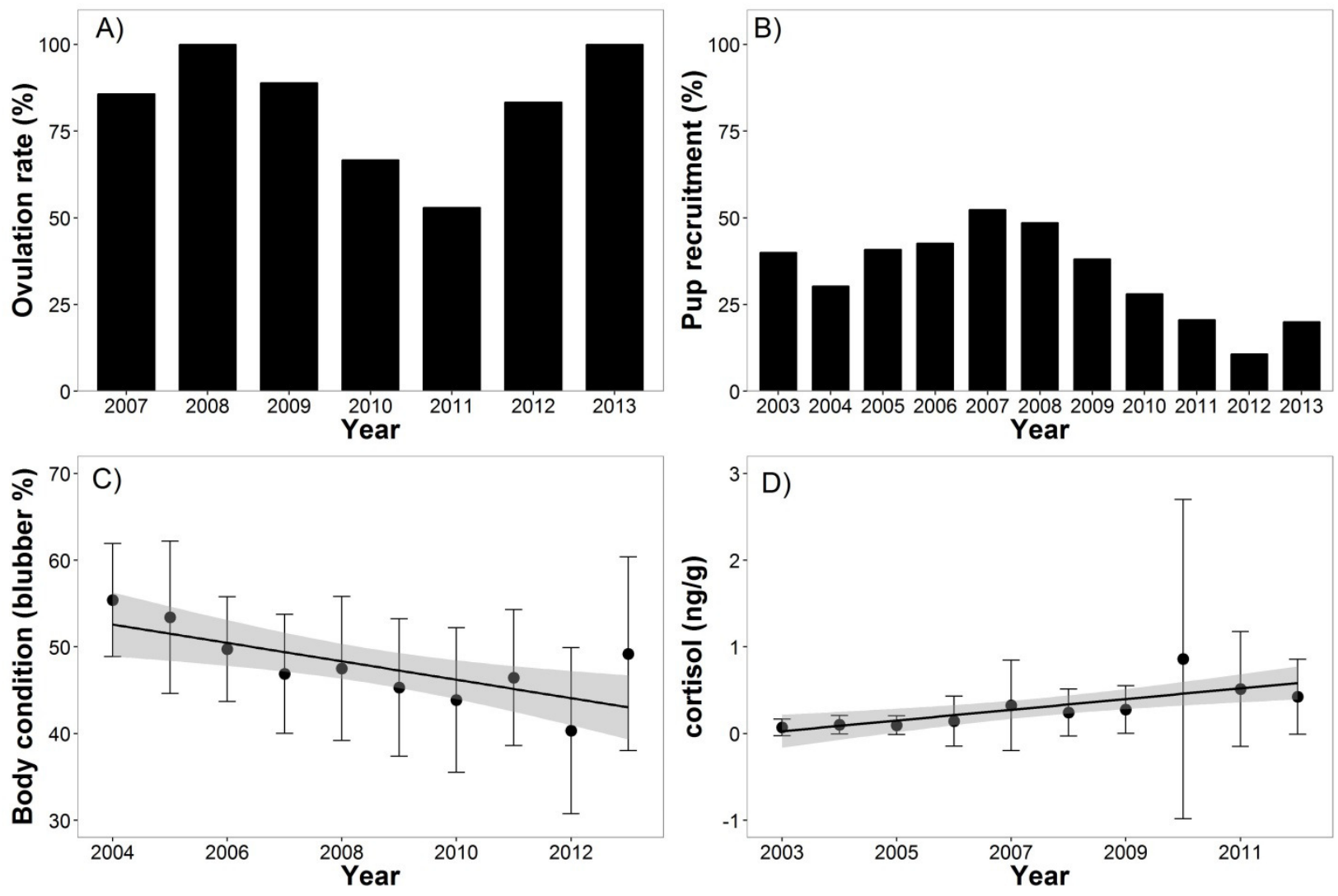
205 Figure 3. Linear regressions between ringed seal body condition and ice-free duration (A;

206 slope $=-0.0004, \mathrm{t}=-2.0, \mathrm{p}<0.05)$, body condition and El-Nino Southern Oscillation (ENSO)

207 index (B; slope $=-0.009, \mathrm{t}=-2.32, \mathrm{p}=0.02)$, body condition and North Atlantic Oscillation

208 (NAO) index (C; slope $=-0.009, \mathrm{t}=2.0, \mathrm{p}<0.05)$, and cortisol and NAO index (D; slope = -

$2090.02, \mathrm{t}=2.6, \mathrm{p}=0.01)$.
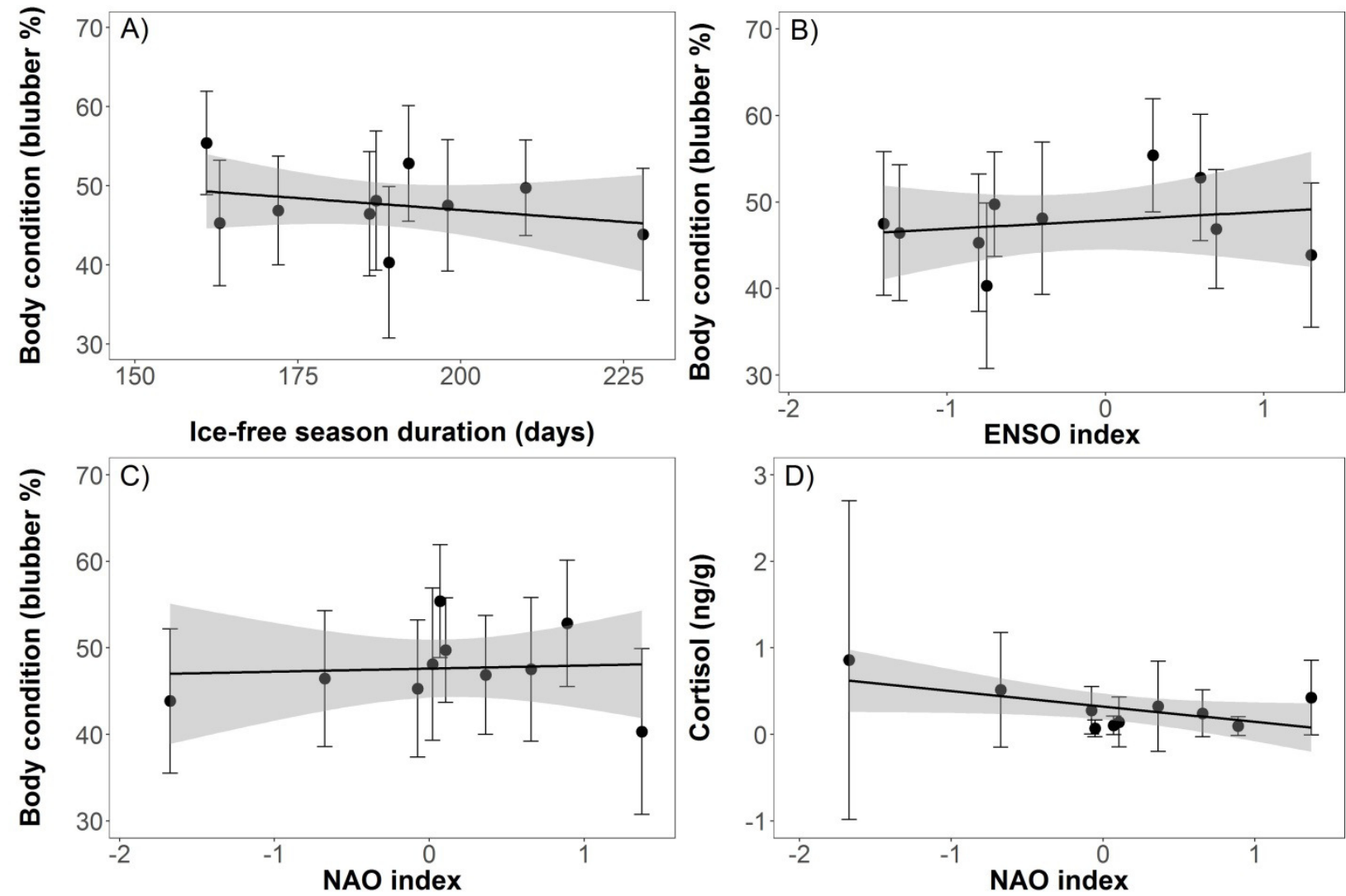
212 We predicted demographic change occurring at the southern limit of the ringed seal

213

214

215

216

217

218

219

220

221

222

223

224

225

226

227

228

229

230

231

232

233

distribution with both gradual changes in environmental variables and episodic events associated with extreme lows in sea ice concentration. Our results suggest both patterns have occurred in southern Hudson Bay over the past decade. Previous research has indicated that Hudson Bay ringed seals (Chambellant et al. 2012) and polar bears (Regehr et al. 2007; Lunn et al. 2016; Obbard et al. 2016) have shown gradual reductions in body condition and survival over the past decades which are concurrent with negative consequences of continued environmental change (Holst et al. 1999; Ferguson et al. 2005). We provide additional evidence for a continuation of these progressive patterns for ringed seals with decreasing body condition and increasing stress over 2003-2013. However, no research results have suggested short-temporal pulses in condition and abundance (i.e., Young et al. 2015) for either seals or polar bears in the Hudson Bay ecosystem, although a regime shift likely occurred in late 1990s (Gaston et al. 2012). Here, we document for the first time, a relationship with ringed seal demographics and the 2010 climatic event that resulted in a punctuated decrease in ovulation, reduced body condition, and increased cortisol levels. Reduced seal pups in the following autumn harvest would likely follow with a lag effect (Ferguson et al. 2005; Iacozza and Ferguson 2014). Ringed seals display a remarkable ability to adjust their body condition and reproduction with different environmental conditions as exemplified by the return to high ovulation levels and body condition (\% fat) in the years following the 2010 extreme event. However, age structure would likely maintain a record of a cohort effect with a reduced number of seals moving through the population over time. 

villosus) and sand lance (Ammodytes spp.) and decrease in Arctic cod (Boreogadus saida)

237 abundance in Hudson Bay since 2000 has caused dietary shifts from endemic Arctic cod to sub-Arctic capelin and sand lance in Arctic marine megafauna including sea birds (Gaston et al. 2003), beluga whales (Delphinapterus leucus; Kelley et al. 2010), and ringed seals (Chambellant et al. 2012). In addition, the isotopic niche size of Hudson Bay ringed seals is significantly larger than individuals from higher latitudes which principally consume Arctic cod, indicating a more diverse and omnivorous diet (Young and Ferguson 2013; Yurkowski et al. 2016a, b). Among ringed seal prey items, Arctic cod represent the highest energy content compared to other fish and invertebrate species (Weslawski et al. 1994; Hedeholm et al. 2011; Harwood et al. 2015). Thus, a recent change in Hudson Bay ringed seal diet due to shifts in forage fish availability and abundance may have negatively impacted ringed seal body condition.

Assessing the causes of an episodic event is more difficult to establish. The extremely low extent and duration of the 2010 ice-covered period in Hudson Bay may have adversely affected the abundance, availability and distribution of prey resources but it is unlikely to have triggered a punctuated decrease in their physiological and energetic demands. We summarized anecdotal evidence for an episodic event affecting the abundance and body condition of ringed seals in Hudson Bay related in 2010-11 (see supplementary material). Anecdotal observations in 2010 are suggestive of a hitherto never before seen event causing impaired biological responses in ringed seal behaviour

256 including unusual approachability, lethargy, and increased tendency for hauling out on 
257 land, possibly due to associated respiratory problems that were first seen during that

258 autumn season. Polar bears are thought to have benefited from this behavior since affected

259 seals were easily captured but no estimate of predation over and above normal could be

260 calculated. Evidence for a biological response to an episodic environmental event comes

261 from the low ringed seal density observed between spring 2010 and 2013 surveys and the

262 unusual environmental patterns that suggest a possible shift in seal condition after 2010.

263 Evidence for a dramatic decline in ringed seal abundance associated with the 2010

264 climatic event in Hudson Bay is both anecdotal (Supplementary Table) and circumstantial

265 (aerial survey abundance estimates; Young et al. 2015). The mechanism of such a decline is

266 not well understood but we postulate that it may be linked to the inability of the seals to

267 properly moult in spring due to a lack of a resting platform with the early loss of sea ice

268 which sets up a physiological predisposition for disease. In addition, hyperthermia in

269 autumn when seals are at their maximum blubber fatness (Young and Ferguson 2013) may

270 be a potential mechanism for the observations of lethargy and use of tidal flats resulting in

271 greater polar bear predation (Supplementary Table). The evidence for a decline in Hudson

272 Bay ringed seal body condition from 2003 to 2013 has statistical support and continues a

273 pattern previously reported (Stirling 2005). Periods of declines in ringed seal body

274 condition have been documented in the western Canadian Arctic (Harwood et al. 2012) and

275 Svalbard (Hamilton et al. 2015) as well as periods of improving body condition in western

276 Hudson Bay (Chambellant et al. 2012). In all cases, top down predation is not considered

277 the agent of change but rather bottom up changes in food supply.

Longer periods of open-water have been linked to access to more food for ringed

279 seals allowing for a longer period of fattening (Young and Ferguson 2013). Possible 
280 explanations for this novel pattern of decreased ringed seal condition with a warming 281 ocean include (1) a shift in the types of forage fish available that result in lower lipid intake 282 - a requirement for ringed seals with their large blubber biomass (Gaden et al. 2009;

283 McKinney et al. 2013; Yurkowski et al. 2016a, b); (2) greater competition from temperate 284 species making forays into the subarctic (Finley et al. 1990; Berg et al. 2010); (3) greater 285 predation effect from new predators moving into areas from which they were previously 286 excluded by sea ice forcing ringed seals to compromise foraging activities in favor of 287 predator avoidance (Laidre et al. 2008; Higdon and Ferguson 2009); and (4) new or 288 increased disease arising from physiological stress associated with warmer temperatures 289 (Pounds et al. 2006; Burek et al. 2008). For Hudson Bay we found ringed seal condition 290 problems linked to large scale climatic patterns that likely cycle over multiple years and 291 possibly explain the periods of good (Chambellant et al. 2012) and bad (this study) in 292 Hudson Bay. However, the mechanistic link between early spring breakup and late ice 293 formation and poor seal condition is not well understood possibly because it has been 294 rarely observed (Ferguson et al. 2005). An Unusual Mortality Event was declared in 2011 by the US government due to a 'new' ulcerative-dermatitis-disease-syndrome of unknown etiology observed in Alaskan ice seals and Pacific walrus (Atwood et al. 2015) that resulted in significant pathology of the 298 lung, liver, immune system, and skin of the seals (Barbosa et al. 2015; Bowen et al. 2015). As observed in Hudson Bay, the affected ice seals displayed uncommon behaviours such as unusual approachability, lethargy, and increased tendency for hauling out on land, as well as respiratory problems. There was some mortality associated with the disease syndrome; 
302 however reliable baseline abundance estimates were not available to assess its 303 significance.

304 Potential repercussions of a gradual sea ice decline and punctuated decreases in 305 some years include a continual reduction in ringed seal body condition and greater stress

306 leading to implications on their demographics. The years marked by extremes in climatic

307 indices (Fig. 1) are associated at higher latitudes with excessive sea ice extremes; whereas

308 our results at the southern range of ringed seals indicate a lack of sea ice may have

309 attributed to decreased body condition, increased stress, and low ovulation rates and pup

310 recruitment. Spring 2010 recorded an unusually early ice breakup that may have

311 predisposed seals to a delayed molt. In the fall of 2010, numerous (100's) moribund seals

312 were found in distress along the shore of western and eastern Hudson Bay suggesting that 313 both regions were affected.

314 Numerous examples of episodic events causing major ecological shifts include 315 regime shifts (Hughes et al. 2013), continental growth (Santosh 2013), drought (Ireland et 316 al. 2012), disease (Pickles et al. 2013), and range shifts due to climate (Baker et al. 2008;

317 Seppä et al. 2009; Chen et al. 2011). For ringed seals, the literature suggests periods of 318 ringed seal crashes in abundance associated with poor reproduction during significant 319 heavy ice years. Variation in ringed seal density associated with ENSO events include 1973 320 (Smith and Stirling 1978), 1992 (Ferguson et al. 2005), 1998 (Smith and Harwood 2001), 321 and in 2010 (Fig. 1). Evidence of high latitude regime shifts include 1977 and 1989 (Hare 322 and Mantua 2000), 1998-99 (Litzow 2006; Benson and Trites 2002). Also, the Greenland 323 Blocking Index for 2010 was the highest year in the annual, spring, winter and December 324 series, 1851-2015 (Hanna et al., 2016). Synchronous fluctuations of seabird species across 
325 the entire Arctic and sub-Arctic regions were associated with changes in sea surface

326 temperatures that were linked to two climate shifts, in 1977 and again in 1989 (Irons et al.

327 2008), and 1998 (Flint 2013), including Hudson Bay in 1998 (Gaston et al. 2003). Major

328 atmospheric patterns suggest that we can expect episodic events occurring once every 10-

32915 years and that they are largely unpredictable in timing but have major consequences on

330 ecosystem structure and function (Ottersen et al. 2004).

331 CONCLUSIONS

332 Considerable uncertainties exist with deciphering past patterns to determine possible

333 cause and effect relationships among environmental variation, body condition, and their

334 demographic responses. However, mounting evidence indicates endemic Arctic species,

335 such as ringed seals, are under immense pressure from climate change and complex spatio-

336 temporal shifts in ecology have subsequently resulted in decreased abundance as a

337 harbinger of range shift. Managers need to be wary of climate change culminating in both a

338 gradual decline in condition and unpredictable episodic events that when combined can

339 have major abundance and distribution consequences.

340 ACKNOWLEDGEMENTS

341 We thank the Inuit hunters and the Hunters and Trappers Association of Arviat and

342 Sanikiluaq, NU, Canada, for conducting community-based seal collections. Reviews by J.

343 Higdon, R. Hodgson, N. Pilfold, and two anonymous reviewers improved the manuscript. 


\section{REFERENCES}

346

347

348

349

350

351

352

353

354

355

356

357

358

359

360

361

362

363

364

365

Atwood, T., Peacock, E., Burek-Huntington, K., Shearn-Bochsler, V., Bodenstein, B., Beckmen, K. and Durner, G., 2015. Prevalence and spatio-temporal variation of an alopecia syndrome in polar bears (Ursus maritimus) of the southern Beaufort Sea. Journal of wildlife diseases, 51(1), pp.48-59.

Baker, A.C., Glynn, P.W. and Riegl, B., 2008. Climate change and coral reef bleaching: An ecological assessment of long-term impacts, recovery trends and future outlook. Estuarine, coastal and shelf science, 80(4), pp.435-471.

Barbosa, L., Johnson, C.K., Lambourn, D.M., Gibson, A.K., Haman, K.H., Huggins, J.L., Sweeny, A.R., Sundar, N., Raverty, S.A. and Grigg, M.E., 2015. A novel Sarcocystis neurona genotype XIII is associated with severe encephalitis in an unexpectedly broad range of marine mammals from the northeastern Pacific Ocean. International journal for parasitology, 45(9), pp.595-603.

Benson, A.J. and Trites, A.W., 2002. Ecological effects of regime shifts in the Bering Sea and eastern North Pacific Ocean. Fish and Fisheries, 3(2), pp.95-113.

Berg MP, KIERS E, Driessen G, Van Der HEIJDEN MA, Kooi BW, Kuenen F, Liefting M, Verhoef HA, Ellers J. 2010 Adapt or disperse: understanding species persistence in a changing world. Global Change Biology. Feb 1;16(2):587-98.

Bowen, L., Miles, A.K., Stott, J., Waters, S. and Atwood, T., 2015. Enhanced biological processes associated with alopecia in polar bears (Ursus maritimus). Science of The Total Environment, 529, pp.114-120. 
366 Boyce MS. Seasonality and patterns of natural selection for life histories. 1979 American $367 \quad$ Naturalist. Oct 1:569-83.

368

369

370

371

372

373

374

375

376

377

378

379

380

381

382

383

384

385

386

387

Burek KA, Gulland FM, O'Hara T. 2008 Effects of climate change on Arctic marine mammal health. Ecolog. Appl. 18(sp2): S126-34. (doi: 10.1890/06-0553.1)

Chambellant, M. and S.H. Ferguson. 2009. Ageing live ringed seals (Phoca hispida): which 1 tooth to pull? Marine Mammal Science 25: 478-486. DOI: 10.1111/j.17487692.2008.00269.x

Chambellant M, Stirling I, Gough WA, Ferguson SH. 2012 Temporal variations in Hudson Bay ringed seal (Phoca hispida) life-history parameters in relation to environment. J. Mammal. 93, 267-281. (doi:10.1644/10-MAMM-A-253.1)

Chen, I.C., Hill, J.K., Ohlemüller, R., Roy, D.B. and Thomas, C.D., 2011. Rapid range shifts of species associated with high levels of climate warming. Science, 333(6045), pp.1024-1026.

Ferguson SH, Stirling I, McLoughlin P. 2005 Climate change and ringed seal (Phoca hispida) recruitment in western Hudson Bay. Mar. Mamm. Sci. 21, 121 - 135. (doi:10.1111/j.1748-7692.2005.tb01212.x)

Ferguson SH and Higdon JW. 2006 How seals divide up the world: environment, lifehistory, and conservation. Oecologia 150, 318-329. (doi:10.1007/s00442-006-0489$\mathrm{x})$

Finley KJ, Bradstreet MS, Miller GW. 1990 Summer feeding ecology of harp seals (Phoca groenlandica) in relation to Arctic cod (Boreogadus saida) in the Canadian High Arctic. Polar Biology. Oct 1;10(8):609-18. 
388 Flint, P.L., 2013. Changes in size and trends of North American sea duck populations

389

390

391

392

393

394

395

396

397

398

399

400

401

402

403

404

405

406

407

408

409 associated with North Pacific oceanic regime shifts. Marine Biology, 160(1), pp.5965.

Gaden A, Ferguson SH, Harwood L, Melling H, Stern GA. 2009 Mercury trends in ringed seals (Phoca hispida) from the western Canadian Arctic since 1973: associations with length of ice-free season. Environmental science \& technology. Mar $23 ; 43(10): 3646-51$.

Gaston, A.J., Woo, K. and Hipfner, J.M., 2003. Trends in forage fish populations in northern Hudson Bay since 1981, as determined from the diet of nestling thick-billed murres Uria lomvia. Arctic, pp.227-233.

Gaston AJ, Smith PA, Provencher JF. 2012 Discontinuous change in ice cover in Hudson Bay in the 1990s and some consequences for marine birds and their prey. ICES J. Mar. Sci. 69, 1218 - 1225. (doi :10.1093/icesjms/fss040)

Guisan A. and W. Thuiller. 2005. Predicting species distribution: offering more than simple habitat models. Ecology Letters 8: 993-1009.

Hamilton, C.D., Lydersen, C., Ims, R.A. and Kovacs, K.M., 2015. Predictions replaced by facts: a keystone species' behavioural responses to declining arctic sea-ice. Biology Letters, 11(11), p.20150803.

Hanna, E., Cropper, T.E., Hall, R.J. and Cappelen, J., 2016. Greenland Blocking Index 18512015: a regional climate change signal. International Journal of Climatology.

Hare SR, Mantua NJ. 2000 Empirical evidence for North Pacific regime shifts in 1977 and 1989. Prog. Oceanog. 47, 103-145. (doi:10.1016/S0079-6611(00)00033-1) 
410 Harwood LA, Smith TG, Melling H, Alikamik J, Kingsley MC. 2012 Ringed seals and sea ice in 411 Canada's Western Arctic: Harvest-based monitoring 1992-2011. Arctic. Dec 1:377412 90.

413 Harwood LA, Smith TG, George JC, Sandstrom SJ, Walkusz W, Divoky GJ. 2015 Change in the Beaufort Sea ecosystem: diverging trends in body condition and/or production in five marine vertebrate species. Progress in Oceanography. Aug 31;136:263-73.

Hedeholm, R., Grønkjær, P. and Rysgaard, S., 2011. Energy content and fecundity of capelin (Mallotus villosus) along a 1,500-km latitudinal gradient. Marine biology, 158(6),

419

420

421

422

423

424

425

426

427

428

429

430 pp.1319-1330.

Higdon JW, Ferguson SH. 2009 Loss of Arctic sea ice causing punctuated change in sightings of killer whales (Orcinus orca) over the past century. Ecological Applications. Jul $1 ; 19(5): 1365-75$.

Holst M, Stirling I, Calvert W. 1999 Age structure and reproductive rates of ringed seals (Phoca hispida) on the northwestern coast of Hudson Bay in 1991 and 1992. Mar. Mamm. Sci. 15, 1357-1364. (doi:10.1111/j.1748-7692.1999.tb00898.x)

Hughes, T.P., Linares, C., Dakos, V., van de Leemput, I.A. and van Nes, E.H., 2013. Living dangerously on borrowed time during slow, unrecognized regime shifts. Trends in ecology \& evolution, 28(3), pp.149-155.

Hunter, C.M., Caswell, H., Runge, M.C., Regehr, E.V., Amstrup, S.C. and Stirling, I., 2010. Climate change threatens polar bear populations: a stochastic demographic analysis. Ecology, 91(10), pp.2883-2897. 
431 Ireland, A.W., Booth, R.K., Hotchkiss, S.C. and Schmitz, J.E., 2012. Drought as a trigger for 432 rapid state shifts in kettle ecosystems: Implications for ecosystem responses to 433 climate change. Wetlands, 32(6), pp.989-1000.

434

435

436

437

438

439

440

441

442

443

444

445

446

447

448

449

450

451

452

Irons, D.B., Anker-Nilssen, T.Y.C.H.O., Gaston, A.J., Byrd, G.V., Falk, K., Gilchrist, G., Hario, M., Hjernquist, M., Krasnov, Y.V., Mosbech, A. and Olsen, B., 2008. Fluctuations in circumpolar seabird populations linked to climate oscillations. Global Change Biology, 14(7), pp.1455-1463.

Kelley, T.C., Loseto, L.L., Stewart, R.E.A., Yurkowski, M. and Ferguson, S.H., 2010. Importance of eating capelin: unique dietary habits of Hudson Bay beluga. In A Little Less Arctic (pp. 53-70). Springer Netherlands.

Kovacs KM, Lydersen C, 2008 Climate change impacts on seals and whales in the North Atlantic Arctic and adjacent shelf seas. Sci. Prog. 91, 117-150.

Laidre KL, Stirling I, Lowry LF, Wiig Ø, Heide-Jørgensen MP, Ferguson SH. 2008 Quantifying the sensitivity of Arctic marine mammals to climate-induced habitat change. Ecological Applications. Mar 1;18(sp2).

Laws RM. 1956 Growth and sexual maturity in aquatic mammals. Nat. 178, 193-194. (doi:10.1038/178193a0)

Levins, R., 1962. Theory of fitness in a heterogeneous environment - I. The fitness set and adaptive function. Am. Nat. 96, 361-373.

Litzow MA. 2006 Climate regime shifts and community reorganization in the Gulf of Alaska: how do recent shifts compare with 1976/1977? ICES J. Mar. Sci. 63, 1386-1396. (doi: 10.1016/j.icesjms.2006.06.003) 
453 Luque SP, Ferguson SH, Breed GA. 2014 Spatial behaviour of a keystone Arctic marine

454

455

456

457

458

459

460

461

462

463

464

465

466

467

468

469

470

471

472

473

predator and implications of climate warming in Hudson Bay. Journal of

Experimental Marine Biology and Ecology. Dec 31;461:504-15.

Lunn, N.J., Servanty, S., Regehr, E.V., Converse, S.J., Richardson, E. and Stirling, I., 2016.

Demography of an apex predator at the edge of its range-impacts of changing sea ice on polar bears in Hudson Bay. Ecological Applications.

MacArthur, R. H. \& Wilson, E. O. 1967. The Theory of Island Biogeography. Princeton Univ. Press, Princeton.

Mayr, E. 1963. Animal species and evolution. Belknap Press, Harvard Univ. Press, Cambridge, Mass.

McKinney MA, Iverson SJ, Fisk AT, Sonne C, Rigét FF, Letcher RJ, Arts MT, Born EW, Rosing-Asvid A, Dietz R. 2013 Global change effects on the long-term feeding ecology and contaminant exposures of East Greenland polar bears. Global change biology. Aug 1;19(8):2360-72.

Nakamura, T., Yamazaki, K., Iwamoto, K., Honda, M., Miyoshi, Y., Ogawa, Y. and Ukita, J., 2015. A negative phase shift of the winter AO/NAO due to the recent Arctic sea-ice reduction in late autumn. Journal of Geophysical Research: Atmospheres, 120(8), pp.3209-3227.

Nye, J.A., Baker, M.R., Bell, R., Kenny, A., Kilbourne, K.H., Friedland, K.D., Martino, E., Stachura, M.M., Van Houtan, K.S. and Wood, R., 2014. Ecosystem effects of the atlantic multidecadal oscillation. Journal of Marine Systems, 133, pp.103-116. 
474 Obbard M.E., M.R.L. Cattet, E.J. Howe, K.R. Middel, E.J. Newton, G.B. Kolenosky, K.F.

475

476

477

478

479

480

481

482

483

484

485

486

487

488

489

490

491

492

493
Abraham, and C.J. Greenwood. 2016. Trends in body condition in polar bears (Ursus maritimus) from the Southern Hudson Bay subpopulation in relation to changes in sea ice. Arctic Science 2: 15-32.

Ottersen, G., Stenseth, N.C. and Hurrell, J.W., 2004. Climatic fluctuations and marine systems: a general introduction to the ecological effects. Marine ecosystems and climate variation, pp.3-14.

Pickles, R.S., Thornton, D., Feldman, R., Marques, A. and Murray, D.L., 2013. Predicting shifts in parasite distribution with climate change: a multitrophic level approach. Global change biology, 19(9), pp.2645-2654.

Poloczanska, E.S., Babcock, R.C., Butler, A., Hobday, A.J., Hoegh-Guldberg, O., Kunz, T.J., Matear, R., Milton, D., Okey, T.A. and Richardson, A.J., 2007. Climate change and Australian marine life. Oceanography and marine biology, 45, p.407.

Post E, Bhatt US, Bitz CM, Brodie JF, Fulton TL, Hebblewhite M, Kerby J, Kutz SJ, Stirling I, Walker DA. 2013 Ecological consequences of sea-ice decline. Science 341, 519-24. (doi:10.1126/science.1235225)

Pounds JA, Bustamante MR, Coloma LA, Consuegra JA, Fogden MP, Foster PN, La Marca E, Masters KL, Merino-Viteri A, Puschendorf R, Ron SR. 2006 Widespread amphibian extinctions from epidemic disease driven by global warming. Nature. Jan $12 ; 439(7073): 161-7$ 
494 Regehr EV, Lunn NJ, Amstrup SC, Stirling IA. 2007 Effects of earlier sea ice breakup on

495

496

497

498

499

500

501

502

503

504

505

506

507

508

509

510

511

512

513

514 survival and population size of polar bears in western Hudson Bay. The Journal of Wildlife Management. Nov 1;71(8):2673-83.

Rode, K.D., Stricker, C.A., Erlenbach, J., Robbins, C.T., Cherry, S.G., Newsome, S.D., Cutting, A., Jensen, S., Stenhouse, G., Brooks, M. and Hash, A., 2016. Isotopic Incorporation and the Effects of Fasting and Dietary Lipid Content on Isotopic Discrimination in Large Carnivorous Mammals. Physiological and Biochemical Zoology, 89(3), pp.182-197.

Rustic, G.T., Koutavas, A., Marchitto, T.M. and Linsley, B.K., 2015. Dynamical excitation of the tropical Pacific Ocean and ENSO variability by Little Ice Age cooling. Science, 350(6267), pp.1537-1541.

Santosh, M., 2013. Evolution of continents, cratons and supercontinents: building the habitable Earth. Current Science(Bangalore), 104(7), pp.871-879.

Saucier FJ, Senneville S, Prinsenberg S, Roy F, Smith G, Gachon P, Caya D, Laprise R. 2004 Modelling the sea ice-ocean seasonal cycle in Hudson Bay, Foxe Basin and Hudson Strait, Canada. Climate Dynamics. Sep 1;23(3-4):303-26.

Seppä, H., Alenius, T., Bradshaw, R.H., Giesecke, T., Heikkilä, M. and Muukkonen, P., 2009. Invasion of Norway spruce (Picea abies) and the rise of the boreal ecosystem in Fennoscandia. Journal of Ecology, 97(4), pp.629-640.

Smith TG, Harwood LA. 2001 Observations of neonate ringed seals, Phoca hispida, after early break-up of the sea ice in Prince Albert Sound, Northwest Territories, Canada, spring 1998. Pol. Biol. 24, 215-219. (doi:10.1007/s003000000198) 
515 Smith TJ, Stirling I. 1975 The breeding habitat of the ringed seal (Phoca hispida). The birth 516 lair and associated structures. Can. J. Zool. 53, 1297-1305. (doi:10.1139/cjz-2012-

517 0137)

518 Smith TG, Stirling I. 1978 Variation in the density of ringed seal (Phoca hispida) birth lairs in the Amundsen Gulf, Northwest Territories. Can. J. Zool., 56, 1066-1070.

520 (doi:10.1139/z78-149)

521

522

523

524

525

526

527 528

529

530

531

532

533

534

535

Southwood, T.R.E. 1977. Habitat, the templet for ecological strategies? J Anim Ecol 46:337365

Stirling, I., 2005. Reproductive rates of ringed seals and survival of pups in northwestern Hudson Bay, Canada, 1991-2000. Polar Biology, 28(5), pp.381-387.

Stirling, I. and Archibald, W.R., 1977. Aspects of predation of seals by polar bears. Journal of the Fisheries Board of Canada, 34(8), pp.1126-1129.

Stirling, I., N. J. Lunn and J. Iacozza. 1999. Long-term trends in the population ecology of polar bears in western Hudson Bay in relation to climatic change. Arctic 52:294306.

Stirling I, Smith TG. 2004 Implications of warm temperatures and an unusual rain event for the survival of ringed seals on the coast of southeastern Baffin Island. Arctic. Mar 1:59-67.

Thiemann GW, Iverson SJ, Stirling I. 2008 Polar bear diets and arctic marine food webs: insights from fatty acid analysis. Ecolog. Monogr. 78, 591-613. (doi:10.1890/071050.1) 
536 Trana MR, Roth JD, Tomy GT, Anderson WG, Ferguson SH. 2014 Influence of sample

537 degradation and tissue depth on blubber cortisol in beluga whales. J. Exper. Mar.

$538 \quad$ Biol. Ecol. 462, 8-13. (doi:10.1016/j.jembe.2014.10.010)

539 Wang, J., Bai, X., Leshkevich, G., Colton, M., Clites, A. and Lofgren, B., 2010. Severe ice cover

540 on Great Lakes during winter 2008-2009. Eos, 91(5), pp.41-42.

541 Weslawski, J.M., 1994. Diet of ringed seals (Phoca hispida) in a fjord of West Svalbard.

$542 \quad$ Arctic, 47(2), p.109.

543 Young BG, Ferguson SH. 2013 Seasons of the ringed seal: pelagic open-water hyperphagy,

544 benthic feeding over winter and spring fasting during molt. Wildl. Res. 40, 52-60.

$545 \quad$ (doi:10.1071/WR12168)

546 Young, B.G. and Ferguson, S.H., 2014. Using stable isotopes to understand changes in ringed

547 seal foraging ecology as a response to a warming environment. Marine Mammal

$548 \quad$ Science, 30(2), pp.706-725.

549 Young BG, Ferguson SH, Lunn NJ. 2015 Variation in indices of ringed seal density and

$550 \quad$ abundance in western Hudson Bay determined from aerial surveys, 1995 to 2013.

$551 \quad$ Arctic 68, 301-309. (doi:10.1111/j.1748-7692.2005.tb01212.x)

552 Yurkowski DJ, Ferguson SH, Semeniuk CAD, Brown TM, Muir DC, Fisk AT. 2016a. Spatial

553 and temporal variation of an ice-adapted predator's feeding ecology in a changing

554 Arctic marine ecosystem. Oecologia 180:631-644. (doi:10.1007/s00442-015-3384-

$555 \quad 5)$

556 Yurkowski DJ, Ferguson SH, Choy E, Loseto L, Brown TM, Muir DCG, Semeniuk CAD, Fisk

557 AT. 2016b. Latitudinal variation in ecological opportunity and intra-specific competition 
558 indicates differences in niche variability and diet specialization of Arctic marine

559 predators. Ecology and Evolution 6:1666-1678

560 
561 Supplementary Table1. 1971-2014 NAO, AO, ENSO, and eastern Hudson Bay breakup and 562 freeze-up from 1979 to 2014.

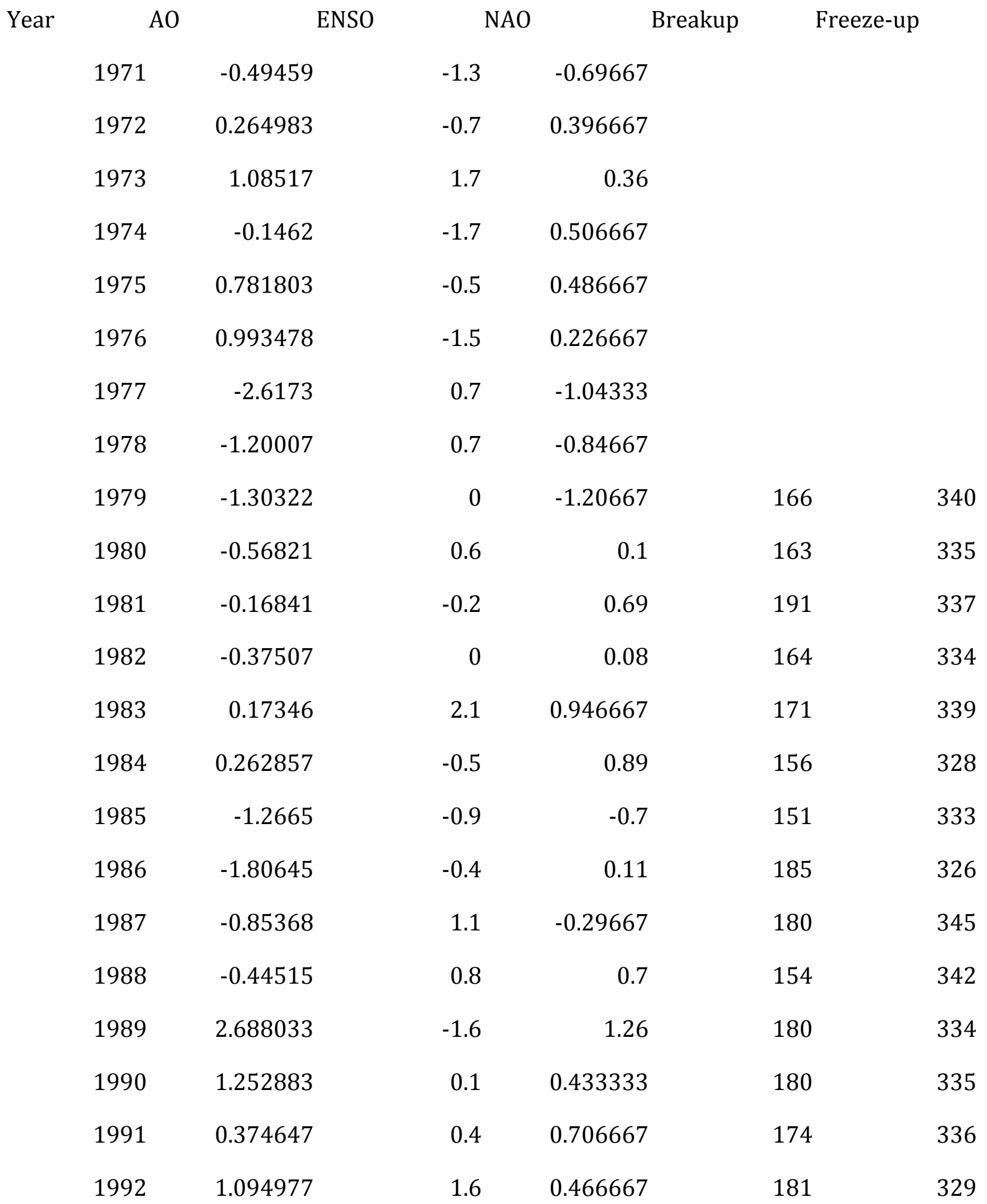




\begin{tabular}{|c|c|c|c|c|c|}
\hline 1993 & 1.768833 & 0.2 & 0.856667 & 169 & 328 \\
\hline 1994 & -0.41784 & 0.1 & 1.02 & 180 & 348 \\
\hline 1995 & 0.722987 & 0.9 & 1.363333 & 173 & 334 \\
\hline 1996 & -1.05476 & -0.9 & -0.62 & 184 & 357 \\
\hline 1997 & -0.09629 & -0.5 & -0.06667 & 164 & 330 \\
\hline 1998 & -0.7783 & 2.1 & -0.22667 & 159 & 352 \\
\hline 1999 & 0.648627 & -1.4 & 0.643333 & 146 & 350 \\
\hline 2000 & 1.1297 & -1.6 & 1.303333 & 157 & 351 \\
\hline 2001 & -1.31188 & -0.7 & 0.04 & 150 & 361 \\
\hline 2002 & 0.454133 & -0.2 & 0.236667 & 171 & 338 \\
\hline 2003 & -0.64532 & 0.9 & -0.05333 & 185 & 362 \\
\hline 2004 & -0.98303 & 0.3 & 0.07 & 177 & 338 \\
\hline 2005 & 0.105223 & 0.6 & 0.89 & 158 & 350 \\
\hline 2006 & -0.81005 & -0.7 & 0.104837 & 145 & 355 \\
\hline 2007 & 1.002867 & 0.7 & 0.36307 & 173 & 345 \\
\hline 2008 & 0.859387 & -1.4 & 0.6561 & 150 & 348 \\
\hline 2009 & 0.25841 & -0.8 & -0.07584 & 184 & 347 \\
\hline 2010 & -3.42177 & 1.3 & -1.67293 & 141 & 369 \\
\hline 2011 & -0.9129 & -1.3 & -0.67427 & 163 & 349 \\
\hline 2012 & 0.654935 & -0.7 & 1.371767 & 159 & 348 \\
\hline 2013 & -1.12184 & -0.4 & 0.02096 & 159 & 346 \\
\hline 2014 & 0.183305 & -0.5 & 0.85704 & 168 & 341 \\
\hline
\end{tabular}


564 Supplementary Table2. Chronology of unusual ringed seal and polar bear observations 565 gathered from Hudson Bay communities related to a warming event in 2010.

Date Comment Reporter

4 Nov. 2010 I've only seen about 3 kills in the 11 years I've worked for Marc Hebert, you guys and now 7 in a month? Manitoba

Conservation Officer

14 Nov. He has also seen quite a few seals and seal kills by Polar Mike Macri (Sea North 2010 Bears. He also flew over Button Bay and saw a number of Tours, Churchill) seal kills that hadn't been consumed.

16 Nov. He states that seals are venturing inland than normal. Amanda Currie (DFO) 2010 Bears are eating seals. The only physical problems or conversation with abnormalities he notes he has seen is one seal that Donnie (Great White appeared to be bleeding from the anus. Sick seals -- Bear tours). showing evidence of hair loss.

16 Nov. Recently found a seal that was still alive but crawling over LeeAnn Fishback 2010 land near the Rx road just out of the Town of Churchill. $\quad$ (CNSC) with Manitoba Conservation

17 Nov. First Vince had heard of dead seals. But noted Darryl Ole Nielson (DFO 2010 Hedman flew coast and saw over 300 bears - saw 18 dead Science) with Vince seals that had been killed so he says by bears - when I Crichton (Manitoba 
asked him how the bears were catching seals he said they Conservation

are likely getting caught on the flats when tide goes out Manager, Game Fur \& and bears just taking advantage of easy meal - maybe Problem Wildlife) something wrong with seals that they are getting caught like this.

18 Nov. They both confirm they're have been no reports of any Tara Bortoluzzi (DFO killer whale sightings in the area, as its too late in the Science) spoke with seasons for Killer Whales. Also the local polar bears are Mike Macri and Bob also very fat, and several appear to be 'stock piling' the seals they catch (i.e. some people have witness and Windsor

(Conservation Officer photographed the bears stock piling or buried seals in Churchill) inland instead of eating them). Mike was on a flight a week ago and saw a fat polar bear kill a seal, walk away and kill another seal on the shore, drag it back to the first, and then walk away without eating either. And another sow with cubs had a dead seal and was not eating it. Another seal was seen moving along RX road about 1-2 $\mathrm{km}$ from shore. Received two pictures of this from Mike Macri.

24 Nov. I met two hunters from Chesterfield Inlet and Whale Cove Ole Nielsen (DFO) 2010 in the Iqaluit airport on Monday that were also very concerned with the 'behavior' of ringed seals near their 
communities this fall. I'm following up with them and several other HTOs. They reported that they are catching more adult seals this year which are really large, and very few pups. The seals are also very easy to catch, in many cases they said 'too easy'. One hunter caught 30 seals in one day trip. The seals are also coming inland and hanging around the shoreline for extended periods of time. Of course, it's great for hunting, but they were really concerned as this is very unusual.

26 Nov. Some of the Hunters and Trappers Organizations in the Tara Bortoluzzi (DF0) 2010 Kivalliq region have recently reported concerns with 'odd summarizing behaviour' of ringed seals near the communities (i.e. seals response from Kivalliq coming close to shore and hanging around, and hauling Region communities out on shore), as well as some seals that appears to be sick (i.e. molting and loss of hair, seal pocks, low fat content, etc.).

26 Nov. She has heard the same concerns from hunters: "After Leah Muckpah (Arviat 2010 discussion with my board of directors, they have reported HTO Manager) some hunters catching seals on shore, and far away from shore with loss of hair (like bald patches) but nobody took pictures and the seals were used as dog food." 
27 Nov. He hasn't seen any more seals on shore, neither have the email from Mike Macri

2010 helicopters or tundra buggy camps. Also notes another (Sea North Tours) odd thing, the zodiacs, for the first time ever, are covered with scratches from bearded seals who were hauling up into them in September.

17 Dec. "A couple weeks ago while he was out of town, Lucasssie Lucassie Arragutainaq 2010 Takatak, found 6 dead seals on the beach, their heads (Secretary Manager seem to be craving for air like their heads up back." Sanikiluaq HTO)

06 Jan. 2011 They observed a very few number of seals were shedding reports from local and that even a few number of them were sinking after hunters of Arviat being shot. The seal harvest in Arviat is usually done when the first ice forms in the salt water, usually late October to Late November. During that time, it is unheard of that seals would be shedding fur and that they would sink after being shot.

26 Jan. 2011 Ringed seals usually molt in the spring but locals noted seals molting in the fall. The local Conservation Officer Ferguson phone sent seal parts to DFO showing the unusual molt. During Noah Nakoolak of fall large numbers (100s) of seals were observed along Coral Harbour HTO shorelines. Other communities including Repulse Bay also noted the same unusual conditions. Coral Harbour 
seldom sees seals near town but this past fall large

numbers were in the Harbour and some went on land in the harbour (very unusual).

His own personal experience - he was traveling along shoreline in August and found a seal on the beach. The ringed seal kept traveling up the shore - unusual behaviour. Three weeks later he was in a different area and saw a harp seal on land - about $1 / 4$ mile inland. It was a late freeze up this autumn and a very warm fall. The ice formed along the shoreline twice in mid-November but drifted off with winds both times before it finally formed fast in December. In December rain fell. 